\title{
THE ECONOMIC EFFECTS OF LEVYING A HARBOR USER CHARGE ON WATERBORNE COMMERCE
}

\author{
Charles L. Trozzo and H. Craig Davis*
}

\section{Introduction}

There has been a long-standing interest in imposing user fees on waterborne traffic (see, e.g., Charles River Associates, 1970; Heggie, 1974; Walters, 1975; Anderson et al., 1977a, 1977b; Imakita, 1978; Walton, 1979; Salzano, 1981; Tomassoni, 1981). Since October 1980 the U.S. federal government has collected a fee in the form of a tax on vessel fuels from vessels using the inland waterways. Within the last two sessions of Congress, both members of administration and individual members of Congress have made serious legislative initiatives to impose charges on commercial vessels moving in the channels of the deep water ports on the United States' coasts and Great Lakes. One of the purposes of such proposals is to generate revenues of over $\$ 300$ million, the amount the U.S. Army Corps of Engineers expends annually on deep water harbor maintenance.

Except for inconsequential tonnage duties on vessels engaged in foreign trade, which have been in effect since the 19th century, foreign and domestic vessels have moved in and out of the U.S. deep water port system without significant federal fees. ${ }^{1}$ Instituting the new charge at coastal and Great Lakes ports would be a discrete break with the past, potentially affecting an enormous quantity of domestic and international commerce. The Corps of Engineers estimates that in 1979 there moved through U.S. ports 633 million tons of imports, 360 million tons of exports, and 448 million tons of domestic coastal and

\footnotetext{
* Bushnell, Pearsall and Trozzo Inc., Alexandria, Virginia, and Associate Professor, School of Community and Regional Planning, University of British Columbia. This study was supported by the Economic Development Administration, U.S. Department of Commerce, Project No. RED-790-G-82-8 (99-7-13598). The authors gratefully acknowledge the contributions to this study of Drs. Everard M. Lofting, Edward S. Pearsall and Robert C. Bushnell.
}

Great Lakes shipments. Total deep water commerce in that year amounted to more than 1.4 billion tons.

To the extent that any U.S. waterborne commerce would be affected by a user charge, the impacts created by such a charge would extend well beyond the change in the quantities of the goods moving through U.S. ports. Not only would the shipping industry carrying the goods be affected by these changes, but also the port activities, industries producing or consuming the shipped goods, and the numerous suppliers of the other goods and services used by all of these industries in their production processes.

The objective of this paper is to investigate the range and magnitude of these impacts. Toward this end, the analysis focuses on the changes that might have occurred in 1979 had the federal government then instituted a nationwide uniform charge of $\$ 0.25$ per ton on cargo-exports, imports and unloadings of domestic shipments-moved through U.S. deepwater ports. While this particular levy is not prescribed by any of the legislative proposals, it is approximately the charge that would be needed to cover the operation and maintenance costs incurred by the U.S. Army Corps of Engineers for U.S. deepwater coastal and Great Lakes ports. The results illustrate the potential impacts that can result from the imposition of a charge on deepwater foreign and domestic commerce.

\section{Methodology}

The impacts on economic activities resulting from the imposition of a port user fee were estimated in this study from three different perspectives: impacts on activities directly associated with ports and within the hinterlands of the ports; impacts on activities located within particular geographically defined port areas; and impacts on particular economic sectors on a nationwide basis.

It is to be stressed that the analysis presented is an impact analysis, not an evaluation 
analysis. The former attempts to measure the changes in selected variables resulting from a narticular initiative while the latter is designed to assess the desirability of the initiative by weighing the various changes in terms of goals or objectives, explicitly recognizing in the process the opportunity costs of the resources utilized in the implementation of the initiative (Waters 1976).

\section{Port/Shipping and Hinterland Impacts}

In the study, a distinction is drawn between "port/shipping" economic activities and portdependent or "hinterland" activities. In the first instance, the impact of the harbor user fee is measured in terms of the economic impact originating in the port and shipping industries. Given the increases in prices of exports and imports caused by the user fee, coefficients of price elasticities of demand for various commodities were used to translate the price increases into reduced demands for the exports and imports of particular commodities. The resulting reductions in trade flows have a direct impact on port/shipping activities which is subsequently translated into reduced indirect and induced demands on the nation's production. (The indirect impact in this case consists of the changes in all activities supporting port/shipping activities through technical relationships, i.e. sales/purchases of intermediate commodities. The induced impact is composed of changes in activities attributable to reduced consumption resulting from lower incomes). The total impact of the reduced port activity on production is estimated via a national input-output table as

$$
\Delta \mathrm{X}_{\mathrm{P}}=(\mathrm{I}-\mathrm{A})^{-1} \Delta \mathrm{PA}
$$

where $\Delta \mathrm{X}_{p}$ is the vector of changes in gross outputs of all sectors in the economy due to the reduction, $\triangle \mathrm{PA}$ in port/shipping activity, and $(\mathrm{I}-\mathrm{A})^{-1}$ is the customary Leontief inverse of the input-output model (closed with respect to household consumption).

A second set of impacts is transmitted through the aggregate of hinterland industries that produce exports, that use imports for which there are no readily available domestic substitutes, and that produce commodities which serve as import replacements. Decreases in exports result in reduced business transactions by the export-producing industries, with consequent indirect and induced effects of sup- pliers and income earners employed in those industries. The decline in gross outputs, $\Delta \mathbf{X}_{\mathrm{E}}$, due to a reduction in exports, $\Delta \mathbf{E X}$, is estimated as

$$
\Delta \mathrm{X}_{\mathrm{E}}=(\mathrm{I}-\mathrm{A})^{-1} \Delta \mathrm{EX}
$$

To the extent that decreased imports are replaced by domestic production, the sales of the domestic industries producing such products will increase. The potential impact in such cases-i.e., the change in gross outputs, $\Delta \mathrm{X}_{c}-$ can be estimated as

$$
\Delta \mathrm{X}_{c}=(\mathrm{I}-\mathrm{A})^{-1} \Delta \mathrm{CM}
$$

where $\triangle \mathrm{CM}$ is the change in competitive imports.

Finally, decreases in imports for which there are no substitute U.S. products will result in restricted levels of production in those industries for which the imported products are necessary inputs. In such cases it is assumed, in accordance with the fixed production requirements of the input-output model, that the percent reduction of the gross output of the industry in question is equal to the percent reduction in non-competitive imports. The reduction in gross outputs, $\Delta \mathbf{X}_{N}$, due to decreases in sector outputs, $\overline{\Delta \mathrm{X}}$, directly attributable to reduction in non-competitive imports is thus estimated as

$$
\Delta \mathrm{X}_{N}=\overline{(\mathrm{I}-\mathrm{A})^{-1}} \overline{\Delta \mathrm{X}}
$$

where $(I-A)^{-1}$ is a matrix in which each column entry $r_{i j}$ has been divided by $r_{j j}$ in order to transform the inverse matrix into one which is appropriately applied to changes in gross outputs rather than changes in final demands (Davis 1983).

The total change in gross outputs, $\Delta \mathbf{X}_{T}$, resulting from the imposition of a user charge on waterborne traffic can now be estimated as

$$
\Delta \mathrm{X}_{T}=\Delta \mathrm{X}_{P}+\Delta \mathrm{X}_{E}+\Delta \mathrm{X}_{C}+\Delta \mathrm{X}_{N}
$$

\section{Geographic Impacts}

A second perspective for considering the impacts that arise is the approximate geographic distribution of those impacts. In this analysis, the deep water ports are grouped into six areas, the North Atlantic, South Atlantic, Gulf of Mexico, California (including Hawaii), Pacific Northwest (including Alaska) and the Great 
Lakes. For each of these areas, the study estimates the impacts arising because of any decrease in traffic handled by the area's port/ shipping industry and the impacts affecting the "hinterland industries" serving the area.

In the results reported below, the geographic area of the "port/shipping industry" utilizing a particular port is not strictly defined. The more appropriate interpretation of the empirical results is that they are the impacts imposed on the port/shipping industry in the particular port area and the suppliers supporting that area's port/shipping servicing system. Similarly, the hinterland, supplying exports or consuming imports moving through a particular port area, is not strictly locationally delineated by our six geographic divisions and could well encompass a substantial part of the total spatial economy for any particular commodity.

\section{Sector Impacts}

Finally, the impacts on both the "port/shipping industry" and the "hinterland industries" can be disaggregated according to more specific industry/product sectors. This helps to define more precisely the industry breakdown of the economic effects that ultimately result after transmission of the impacts through the system is complete. In the following discussion, the impacts are traced through 30 industry/ product sectors. These 30 sectors are aggregations of the original 476 sector breakdown of the economy that makes up the input-output model used to trace and calculate the impacts set in motion as a result of the user fee.

It is important to note, however, that the impacts estimated for each of the above categories by equations (1)-(5) omit some important considerations. The analysis takes into account only those changes that take place in the volume of imports, exports and domestic commerce in response to the initial charge per ton of cargo. The charge, however, would probably have cumulative effects. That is, to the extent that commodities bearing the charge are inputs to other commodities, the prices of the latter, as well as those of commodities using the latter as inputs, can be expected to rise. In turn, these price increases may come to affect the volume of trade. For example, to the extent that any increase in the price of phosphates, stemming from the levying of the charge on domestic deepwater movements of phosphates, results in higher grain prices at the farm, ex- ports of grain can be expected to decline accordingly. Similarly, industries producing commodities in competition with imports might find that the advantage bestowed on them by the charge on imports is actually less than first appears because the prices of some of their inputs may be increased as a result of the charge.

A second major omission is the economic effect of the government's use of the revenues generated by the user charge. However, the use of these funds is a major fiscal policy question with quite different results arising from each of the several options that might be followed for their disposition. Investigating that very wide range of possible outcomes is clearly outside the scope of this work.

Additionally, no attempt was made in this study to estimate the multiplier effects of reduced waterborne commerce other than the direct, indirect and induced effects discussed above in regard to equations (1) to (5). No attempt was made, for example, to take into account the impact of reduced capital investment in, say, port and carrier equipment that might result from a decline in waterborne traffic. Similarly, it can be expected that significant decreases in the sales of suppliers would lead to cutbacks in investment in plant and equipment. These reduced volumes of capital investment could be expected, in turn, to lead to additional rounds of decreased sales and incomes, generating a downward investment multiplier effect.

Finally, any decrease in U.S. imports constitutes decreased sales and foreign exchange earnings by the foreign suppliers of the imported goods. These lower sales and exchange earnings would lead to lower incomes for the foreign supplying countries. Because foreign demand for U.S. goods is determined in large measure by foreign incomes, demands for U.S. exports could be expected to decline further, initiating a trade multiplier effect. To the extent that these latter two multiplier effects are significant, the estimates of the impacts in this analysis can be judged to be conservative.

\section{The Data}

The base year of the analysis is 1979 , the most recent year for which the necessary data on waterborne commerce were available. It was also a year in which there were neither 
extraordinary factors affecting this commerce, nor macroeconomic conditions which might significantly distort the results of the analysis.

The data on 1979 deepwater commerce were obtained from the U.S. Bureau of the Census and the U.S. Maritime Administration. The Bureau of Census annually publishes a summary derived from Customs reports of imports arriving by water transportation at the various customs districts. These imports are identified by country of origin and the commodity codes of the Tariff Schedules of the United States (U.S. Bureau of Census, 1979a). The Bureau also publishes an annual summary of exports moving by water out of the same customs districts, identified by country of destination and specific export commodity codes (U.S. Bureau of Census, 1979b). Both imports and exports are reported by weight and value.

The Maritime Administration utilizes for its reports the data on waterborne commerce assembled each year by the U.S. Army Corps of Engineers, covering separately the domestic coastal and Great Lakes movements (U.S. Department of the Army, 1979). These data are reported by weight only for both shipping and receiving ports and are identified by a commodity code specially developed for the waterborne commerce statistical series. These data were processed into the framework of the input-output model used in the analysis by mapping the series' commodity codes into the appropriate I-O sector definitions. Further processing was undertaken to develop tables of imports, exports, and domestic shipments and receipts for each of the six port areas as well as national totals.

Given the tonnage flows and values tabulated as described above, it was possible to develop unit values for both imports and exports at each port area. These values were then used with price elasticity coefficients (Buckler and Almon 1972, Baldwin 1976) to calculate the changes in the tonnages that would move through each port area as a result of the increase in commodity prices caused by the user charge.

These elasticities are a crucial element of the analysis and the estimates used are particularly appropriate to the study in that they were originally constructed for the commodity classification of the U.S. input-output model. The estimation process was undertaken as a part of the U.S. Department of Labor's efforts to assess the effects of alternative provisions in trade agreement negotiations and the results are based on commodity data consistent with those of the record of port traffic used in this study. As a further measure, additional efforts were undertaken to confirm the reasonableness of the elasticity values relative to other such estimates made for major tonnage commodities such as grain and fuels (Bushnell et al. 1984). It was assumed in the present study that the user charge would be passed on by carriers and shippers to the ultimate users of the commodities, who would make their full longrun adjustments to the new price.

The construction of economic impact estimates utilizing the above waterborne commerce data is based upon the $\mathbf{4 7 6}$ sector model of the U.S. economy in 1972, developed by the Bureau of Economic Analysis (BEA) in the U.S. Department of Commerce (1979a). This model was independently updated to reflect 1977 industry technology. The specific version of the model augments the original BEA model with a set of six, more detailed waterborne transportation activities developed in a later study by the BEA (1979b), and a set of more detailed mining and minerals sectors developed for the U.S. Bureau of Mines (Lofting and Davis 1982). Price adjustments were applied to the model calculations to state the results in terms of 1979 dollars (Evans 1955).

\section{Empirical Results}

The estimate of the economic impacts of the $\$ 0.25$ charge per ton of waterborne commerce is presented in this section from the three different perspectives: impacts on national port/ shipping and hinterland economic activities; impacts on broadly defined regions of the U.S.; and impacts on individual national economic sectors. From each of the three perspectives, the impact estimates are measured in terms of changes in quantities of cargo shipped, sales, employment, income, tax revenue, customs duties, and the balance of trade.

Estimates of the changes in sales, employment, income and tax revenue were derived directly from the input-output model calculations, utilizing the appropriate multipliers for each measure. The estimates of the changes in customs duties collections and the balance of trade were based on the changes in quantities of cargo shipped, the average duty collected on 
each import, and the F.A.S. value of each import and export as reported by the Bureau of the Census. All impacts are calculated on the basis of fixed technical coefficients, thus excluding consideration of structural changes in the economy (such as technological changes in the transportation sectors) in response to the charge.

\section{National Port/Shipping and Hinterland Impacts}

The overall national impacts of a $\$ 0.25$ per ton charge in 1979 are shown in the last three lines of Table 1. Given the decline in traffic of almost 10 million short tons of cargo in response to the charge, the levy would have generated revenues of $\$ 337$ million. However, the charge would have also brought about declines in employment of more than 10,000 jobs and in incomes of approximately $\$ 260$ million. Income and indirect business tax revenues at the federal, state and local levels would have decreased by almost $\$ 67$ million and the decline in federal customs duties collections would have been more than $\$ 12$ million. Finally, the commodity balance of trade would have decreased by almost $\$ 56$ million.

Of these aggregate effects, those originating in the direct impacts on the port/shipping industry account for less than 25 percent of the total loss in direct business sales. However, the total decreases in employment, income and tax payments resulting from the initial impact on the port/shipping industry account for 30 percent or more of the total decline in those measures. This is because of the differences in the manner and magnitude of the propagation throughout the economy of the direct sales effects on the port/shipping and hinterland industries. For example, the $\$ 39.1$ million (Table

Table 1

Economic Effects of a User Charge on U.S. Deep Water Commerce ALL FOREIGN \& DOMESTIC COMMERCE, TOTAL U.S., 1979 (1979 Dollars)

User Charge $=\$ .25$ per ton of Imports, Exports, Domestic Unloadings

\begin{tabular}{|c|c|c|c|c|c|c|c|c|}
\hline SOURCE & $\begin{array}{l}\text { Direct } \\
\text { Sales } \\
\$ 1000 \\
\end{array}$ & $\begin{array}{l}\text { Employ- } \\
\text { ment } \\
\text { Jobs }\end{array}$ & $\begin{array}{c}\text { Income } \\
\$ 1000\end{array}$ & $\begin{array}{l}\text { Taxes } \\
\$ 1000 \\
\end{array}$ & $\begin{array}{l}\text { Duties } \\
\$ 1000 \\
\end{array}$ & $\begin{array}{l}\text { User } \\
\text { Charge } \\
\$ 1000 \\
\end{array}$ & $\begin{array}{c}\text { Cargo } \\
\text { 1000ST }\end{array}$ & $\begin{array}{c}\text { Commodity } \\
\text { Balance } \\
\$ 1000 \\
\end{array}$ \\
\hline \multicolumn{9}{|c|}{ FOREIGN TRADE EFFECTS } \\
\hline \multicolumn{9}{|c|}{ Comparable Imports } \\
\hline $\begin{array}{l}\text { Port/Shipping Effects } \\
\text { Hinterland Effect }\end{array}$ & $\begin{array}{r}-5771 \\
92209\end{array}$ & $\begin{array}{r}-451 \\
5576\end{array}$ & $\begin{array}{r}-10339 \\
152240\end{array}$ & $\begin{array}{r}-2704 \\
41470\end{array}$ & $\begin{array}{c}-10949 \\
-\end{array}$ & $\begin{array}{c}60132 \\
-\end{array}$ & $\begin{array}{c}-2492 \\
-\end{array}$ & $\begin{array}{c}79808 \\
-\end{array}$ \\
\hline Total & 86438 & $\overline{5125}$ & 141901 & 38766 & $\overline{-10949}$ & $\overline{60132}$ & $\overline{-2492}$ & $\overline{79808}$ \\
\hline \multicolumn{9}{|l|}{ Noncomparable Imports } \\
\hline Port/Shipping Effects & -1639 & -127 & -2927 & -764 & -1198 & 88692 & -143 & 19279 \\
\hline Hinterland Effects & -63372 & -2136 & -71586 & -20369 & - & - & - & - \\
\hline Total & -65011 & $\overline{-2263}$ & -74513 & -21133 & $\overline{-1198}$ & $\overline{88692}$ & -143 & $\overline{19279}$ \\
\hline \multicolumn{9}{|l|}{ Exports } \\
\hline Port/Shipping Effects & -9597 & -746 & -17140 & -4476 & - & 88928 & -2060 & -154905 \\
\hline Hinterland Effects & -154905 & -10286 & -263506 & -68059 & - & - & - & - \\
\hline Total & -164501 & -11032 & -280646 & -72535 & - & $\overline{88928}$ & -2060 & -154905 \\
\hline \multicolumn{9}{|l|}{ Total Foreign Trade } \\
\hline Port/Shipping Effects & -17006 & -1324 & -30406 & -7944 & -12147 & 237755 & -4695 & -55816 \\
\hline Hinterland Effects & -126066 & -6846 & -182852 & -46958 & - & - & - & - \\
\hline Total & $\overline{-143072}$ & -8170 & -213258 & -54902 & -12147 & $\overline{237755}$ & $\overline{-4695}$ & -55816 \\
\hline \multicolumn{9}{|c|}{ DOMESTIC COMMERCE EFFECTS } \\
\hline $\begin{array}{l}\text { Port/Shipping Effects } \\
\text { TOTAL FOREIGN \& } \\
\text { DOMESTIC TRADE }\end{array}$ & -22122 & -1943 & -46787 & -12231 & - & 99092 & -4817 & - \\
\hline $\begin{array}{l}\text { Port/Shipping Effects } \\
\text { Hinterland Effects }\end{array}$ & $\begin{array}{r}-39128 \\
-126066 \\
\end{array}$ & $\begin{array}{l}-3267 \\
-6846 \\
\end{array}$ & $\begin{array}{r}-77193 \\
-182852 \\
\end{array}$ & $\begin{array}{l}-20175 \\
-46958 \\
\end{array}$ & $\begin{array}{r}-12147 \\
- \\
\end{array}$ & $\begin{array}{c}336847 \\
- \\
\end{array}$ & $\begin{array}{r}-9512 \\
- \\
\end{array}$ & $\begin{array}{r}-55816 \\
- \\
\end{array}$ \\
\hline Total & $\overline{-165194}$ & -10113 & $\overline{-260045}$ & -67133 & -12147 & 336847 & $\overline{-9512}$ & -55816 \\
\hline
\end{tabular}


1) of direct sales losses in the port/shipping industry results in a total decline of $\$ 191.8$ million (Table 5a) in business sales when the indirect and induced effects of the $\$ 39.1$ million direct sales decrease are taken into account. Similarly, the loss in direct sales by hinterland industries of $\$ 126.1$ million (Table 1) results in a total of direct, indirect, and induced business sales losses of $\$ 423.9$ million (Table $5 \mathrm{~b}$ ).

As can be seen from columns 1-3 in Table 1(a), these effects are not large compared to the overall size of the economy. At $\$ 0.25$, the user fee program, like most individual government programs, is not quantitatively substantial. However, it is important to consider the "response" (i.e., impacts) being produced per unit of "stimulus" (i.e., user charge) being injected into the system. The measures in column 4 of Table 1(a) are among the principal program criteria that should be taken into account in gauging the merits of a user charge, its magnitude, and the timing of its implementation.
These figures indicate that per dollar of revenue collected by the user charge on all types of deep water commerce, income would decline in 1979 by $\$ 0.77$, federal, state and local income and indirect business taxes would decline by nearly $\$ 0.20$, customs duties would decline by nearly $\$ 0.04$ and the commodity balance of trade would decline a further $\$ 0.17$. In addition, per million dollars of collections, employment would decline by 30 jobs and deepwater commerce would decrease by more than 28,000 tons.

It should also be noted that these figures pertaining to sales, employment, income and taxes are net of the gains registered in the hinterland industries (see Table 1) due to the substitution of domestic production for the now more expensive imports. The full extent of dislocation in the economy is thus not immediately evident from the net figures. For example, greater economic dislocation can be expected from, say, the simultaneous loss of 30

Table 1(a)

National Context \& Relative Program Impacts of the User Charge ALL FOREIGN \& DOMESTIC COMMERCE

\begin{tabular}{|c|c|c|c|c|}
\hline Measure & $\begin{array}{l}1979 \text { Nat'l } \\
\text { Value } \\
\text { w/o user chge } \\
\text { (million) }\end{array}$ & $\begin{array}{c}\text { Change } \\
\text { w/user chge } \\
\text { (million) }\end{array}$ & $\begin{array}{l}\text { Change/ } \\
1979 \text { Value }\end{array}$ & $\begin{array}{c}\text { Change/ } \\
\text { \$ million Rev. }\end{array}$ \\
\hline $\begin{array}{l}\text { Waterborn Commerce (ST) } \\
\text { Employment (jobs) } \\
\text { Income (\$) } \\
\text { Taxes (\$) } \\
\text { Duties (\$) } \\
\text { Waterborne Commodity Balance (\$) } \\
\text { Direct Sales (\$) }\end{array}$ & $\begin{array}{c}1356.9^{*} \\
78.8^{*} \\
1749111.0^{*} \\
446733.2^{*} \\
7202.0^{* *} \\
-45725.0^{*} \\
3575769.0^{*}\end{array}$ & $\begin{array}{c}-9.5 \\
(-.0101) \\
-260.0 \\
-67.1 \\
-12.1 \\
-55.8 \\
-165.2\end{array}$ & $\begin{array}{l}-.0070 \\
-.0001 \\
-.0001 \\
-.0002 \\
-.0017 \\
.0012 \\
\varnothing\end{array}$ & $\begin{array}{r}-28,200 \\
-30 \\
-772,000 \\
-199,300 \\
-36,000 \\
-165,700 \\
-490,400\end{array}$ \\
\hline
\end{tabular}

@ Less than .00005

* Input-Output Model Basis

* Fiscal year 1979 
jobs and the gain of 20 in the economy, as opposed to a gross loss of 10 jobs with no offsetting gains.

\section{Regional Impacts}

Table 2 shows the geographic or regional distribution of the net impacts recorded in the last three lines of Table 1 . This distribution has a number of notable features. Perhaps first among these is the asymmetry of the distribution. The bottom one-third of Table 2 shows that of the total impacts on employment, income and tax payments, half or more fall upon the port area of the Gulf of Mexico and the hinterland industries serving it. The Great Lakes and Pacific Northwest port areas follow, at some distance.

The aggregation of all the impacts obscures the variations across regions of the different types of traffic (imports, exports, domestic shipments/receipts), as well as the industrial composition of the impacts. For example, when the port/shipping impacts are separated from the hinterland impacts, the port/shipping industry in the Great Lakes port area experiences the greatest decline in employment, income, and tax payments. It is followed by the Gulf of Mexico and the North Atlantic areas. However, regarding hinterland industry impacts, the Gulf area's declines in employment, income and tax payments are by far the largest in absolute terms. The Pacific Northwest and Great Lakes port areas follow, with the North Atlantic fairly close behind them.

The North Atlantic and Gulf areas would experience the largest declines in customs duties collections while their positions are reversed in terms of user charge collections. Of special note is the result that the North Atlantic and South Atlantic areas would show a net gain in the commodity balance of foreign trade moving through those areas.

Tables 3 and 4 elaborate on the geographic distribution of the total impacts shown in

Table 2

Economic Effects of a User Charge on U.S. Deep Water Commerce ALL FOREIGN \& DOMESTIC COMMERCE, 1979, BY PORT AREA (1979 Dollars)

User Charge $=\$ .25$ per ton of Imports, Exports, Domestic Unloadings

\begin{tabular}{|c|c|c|c|c|c|c|c|c|}
\hline INDUSTRY/AREA & $\begin{array}{l}\text { Direct } \\
\text { Sales } \\
\$ 1000\end{array}$ & $\begin{array}{l}\text { Employ- } \\
\text { ment } \\
\text { Jobs }\end{array}$ & $\begin{array}{c}\text { Income } \\
\$ 1000\end{array}$ & $\begin{array}{l}\text { Taxes } \\
\$ 1000\end{array}$ & $\begin{array}{l}\text { Duties } \\
\$ 10 u 0\end{array}$ & $\begin{array}{l}\text { User } \\
\text { Charge } \\
\$ 1000\end{array}$ & $\begin{array}{c}\text { Cargo } \\
1000 S T\end{array}$ & $\begin{array}{c}\text { Commodity } \\
\text { Balance } \\
\$ 1000\end{array}$ \\
\hline $\begin{array}{l}\text { Port/Shipping Industry } \\
\text { North Atlantic } \\
\text { South Atlantic } \\
\text { Gulf of Mexico } \\
\text { California } \\
\text { Pacific Northwest } \\
\text { Great Lakes }\end{array}$ & $\begin{array}{r}-8329 \\
-1468 \\
-9493 \\
-3179 \\
-4319 \\
-12339 \\
\end{array}$ & $\begin{array}{r}-677 \\
-121 \\
-771 \\
-268 \\
-358 \\
-1073 \\
\end{array}$ & $\begin{array}{r}-15869 \\
-2841 \\
-18065 \\
-6373 \\
-8465 \\
-25577 \\
\end{array}$ & $\begin{array}{r}-4147 \\
-743 \\
-4721 \\
-1666 \\
-2212 \\
-6685 \\
\end{array}$ & $\begin{array}{r}-4017 \\
-1151 \\
-3964 \\
-1067 \\
-780 \\
-1169 \\
\end{array}$ & $\begin{array}{r}85164 \\
17763 \\
124282 \\
33525 \\
22942 \\
53162 \\
\end{array}$ & $\begin{array}{r}-1946 \\
-237 \\
-1478 \\
-414 \\
-614 \\
-4822 \\
\end{array}$ & $\begin{array}{r}10910 \\
2508 \\
-41021 \\
-683 \\
-16603 \\
-10924 \\
\end{array}$ \\
\hline Total & -39128 & -3267 & -77193 & -20175 & -12147 & 336847 & $\overline{-9512}$ & -55816 \\
\hline $\begin{array}{l}\text { Hinterland Industry } \\
\text { North Atlantic } \\
\text { South Atlantic } \\
\text { Gulf of Mexico } \\
\text { California } \\
\text { Pacific Northwest } \\
\text { Great Lakes }\end{array}$ & $\begin{array}{r}-4631 \\
1585 \\
-91488 \\
-3899 \\
-18116 \\
-9517 \\
\end{array}$ & $\begin{array}{r}-646 \\
-25 \\
-4229 \\
-86 \\
-1172 \\
-688 \\
\end{array}$ & $\begin{array}{r}-12605 \\
944 \\
-122463 \\
-3053 \\
-29053 \\
-16621 \\
\end{array}$ & $\begin{array}{r}-2608 \\
366 \\
-32341 \\
-946 \\
-7353 \\
-4076 \\
\end{array}$ & $\begin{array}{l}- \\
\overline{-} \\
\overline{-} \\
-\end{array}$ & $\begin{array}{l}\overline{-} \\
\overline{-} \\
\overline{-}\end{array}$ & $\begin{array}{l}- \\
\overline{-} \\
\overline{-} \\
-\end{array}$ & $\begin{array}{l}\bar{z} \\
\bar{z} \\
\bar{z}\end{array}$ \\
\hline Total & -126066 & -6846 & -182852 & -46958 & - & - & - & - \\
\hline $\begin{array}{l}\text { North Atlantic } \\
\text { South Atlantic } \\
\text { Gulf of Mexico } \\
\text { California } \\
\text { Pacific Northwest } \\
\text { Great Lakes }\end{array}$ & $\begin{array}{r}-12960 \\
117 \\
-100981 \\
-7078 \\
-22435 \\
-21856 \\
\end{array}$ & $\begin{array}{r}-1323 \\
-146 \\
-5000 \\
-354 \\
-1530 \\
-1761 \\
\end{array}$ & $\begin{array}{r}-28474 \\
-1897 \\
-140528 \\
-9426 \\
-37518 \\
-42198 \\
\end{array}$ & $\begin{array}{r}-6755 \\
-377 \\
-37062 \\
-2612 \\
-9565 \\
-10761 \\
\end{array}$ & $\begin{array}{r}-4017 \\
-1151 \\
-3964 \\
-1067 \\
-780 \\
-1169 \\
\end{array}$ & $\begin{array}{r}85164 \\
17763 \\
124282 \\
33525 \\
22942 \\
53162 \\
\end{array}$ & $\begin{array}{r}-1946 \\
-237 \\
-1478 \\
-414 \\
-614 \\
-4822 \\
\end{array}$ & $\begin{array}{r}10910 \\
2508 \\
-41021 \\
-683 \\
-16603 \\
-10924 \\
\end{array}$ \\
\hline Total & -165194 & -10113 & -260045 & -67133 & -12147 & 336847 & -9512 & -56816 \\
\hline
\end{tabular}


Table 2. Table 3 shows the effects that the projected decline in imports would have across the port areas. Table 4 displays the effects that would result from decreases in exports.

Imports. From Table 3 it can be seen that in tonnage terms the Gulf of Mexico is the largest importing port area. However, the import mix of the North Atlantic port area is apparently more responsive to the $\$ 0.25$ per ton charge so that the North Atlantic experiences the greater traffic decline in imports. Consequently, the employment, income and tax payments of the North Atlantic port/shipping industry would decline by larger amounts than would the Gulf. While the Gulf has the greater revenue collections from the charge, the North Atlantic area would increase its positive commodity trade balance by a larger amount because of its significantly decreased import flows.

The hinterland industry effect, however, is quite different. Because the North Atlantic port area imports commodities for which there are domestically produced replacements, pro- ducers of those goods in the "North Atlantic hinterland" would register increases in sales, employment, income, and tax payments. While the Great Lakes area port/shipping industry was a distant third in the loss of jobs and income as a result of the decline in waterborne import traffic, it ranks second in terms of the sales, employment and income gains by the hinterland industries producing substitutes for these imports.

Also highly notable in the case of import impacts, the "hinterland industries" of the Gulf of Mexico area show a decline in gross output (sales), income payments and tax collections as a result of the decrease in the imports moving through its ports. As can be seen in a finer industry/product breakdown of imports, this consequence in the Gulf port area is due primarily to the cut in imports of crude oil which results in lower production of petroleum products and chemicals in that area. However, because of the difference between (a) employee requirements of the crude petroleum and

Table 3

Ecomomic Effects of a User Charge on U.S. Deep Water Commerce CHANGES IN IMPORTS, 1979, BY PORT AREA (1979 Dollars)

User Charge $=\$ .25$ per ton of Imports, Exports, Domestic Unloadings

\begin{tabular}{|c|c|c|c|c|c|c|c|c|}
\hline INDUSTRY/AREA & $\begin{array}{l}\text { Direct } \\
\text { Sales } \\
\$ 1000 \\
\end{array}$ & $\begin{array}{c}\text { Employ- } \\
\text { ment } \\
\text { Jobs } \\
\end{array}$ & $\begin{array}{c}\text { Income } \\
\$ 1000\end{array}$ & $\begin{array}{l}\text { Taxes } \\
\$ 1000 \\
\end{array}$ & $\begin{array}{l}\text { Duties } \\
\$ 1000 \\
\end{array}$ & $\begin{array}{c}\text { User } \\
\text { Charge } \\
\$ 1000 \\
\end{array}$ & $\begin{array}{c}\text { Cargo } \\
\text { 1000ST }\end{array}$ & $\begin{array}{c}\text { Commodity } \\
\text { Balance } \\
\$ 1000 \\
\end{array}$ \\
\hline $\begin{array}{l}\text { Port/Shipping Industry } \\
\text { North Atlantic } \\
\text { South Atlantic } \\
\text { Gulf of Mexico } \\
\text { California } \\
\text { Pacific Northwest } \\
\text { Great Lakes }\end{array}$ & $\begin{array}{r}-2839 \\
-535 \\
-2517 \\
-503 \\
-326 \\
-690 \\
\end{array}$ & $\begin{array}{r}-221 \\
-42 \\
-196 \\
-39 \\
-26 \\
-54 \\
\end{array}$ & $\begin{array}{r}-5080 \\
-957 \\
-4506 \\
-902 \\
-584 \\
-1236 \\
\end{array}$ & $\begin{array}{r}-1328 \\
-250 \\
-1178 \\
-236 \\
-153 \\
-323 \\
\end{array}$ & $\begin{array}{r}-4017 \\
-1151 \\
-3964 \\
-1067 \\
-780 \\
-1169 \\
\end{array}$ & $\begin{array}{r}44640 \\
7757 \\
74917 \\
9887 \\
5427 \\
6198 \\
\end{array}$ & $\begin{array}{r}-1194 \\
-125 \\
-636 \\
-126 \\
-241 \\
-313 \\
\end{array}$ & $\begin{array}{r}37949 \\
7682 \\
32048 \\
8832 \\
5011 \\
7564 \\
\end{array}$ \\
\hline Total & -7410 & -578 & $-\overline{13265}$ & -3468 & -12148 & 148826 & $\overline{-2635}$ & 99086 \\
\hline $\begin{array}{l}\text { Hinterland Industry } \\
\text { North Atlantic } \\
\text { South Atlantic } \\
\text { Gulf of Mexico } \\
\text { California } \\
\text { Pacific Northwest } \\
\text { Great Lakes }\end{array}$ & $\begin{array}{r}22408 \\
6759 \\
-18419 \\
5616 \\
3501 \\
8971 \\
\end{array}$ & $\begin{array}{r}1381 \\
369 \\
212 \\
544 \\
334 \\
600 \\
\end{array}$ & $\begin{array}{r}38203 \\
10653 \\
-4733 \\
12820 \\
7835 \\
15874 \\
\end{array}$ & $\begin{array}{r}10520 \\
2866 \\
-1979 \\
3284 \\
1980 \\
4430 \\
\end{array}$ & $\begin{array}{l}- \\
- \\
- \\
-\end{array}$ & $\begin{array}{l}- \\
- \\
- \\
- \\
-\end{array}$ & $\begin{array}{l}- \\
- \\
- \\
- \\
-\end{array}$ & $\begin{array}{l}- \\
- \\
- \\
-\end{array}$ \\
\hline Total & 28836 & 3440 & 80652 & 21100 & - & - & - & - \\
\hline $\begin{array}{l}\text { Total } \\
\text { North Atlantic } \\
\text { South Atlantic } \\
\text { Gulf of Mexico } \\
\text { California } \\
\text { Pacific Northwest } \\
\text { Great Lakes }\end{array}$ & $\begin{array}{r}19569 \\
6224 \\
-20936 \\
5113 \\
3175 \\
8281 \\
\end{array}$ & $\begin{array}{r}1160 \\
327 \\
16 \\
505 \\
308 \\
546 \\
\end{array}$ & $\begin{array}{r}33123 \\
9696 \\
-9239 \\
11918 \\
7251 \\
14638 \\
\end{array}$ & $\begin{array}{r}9192 \\
2616 \\
-3157 \\
3048 \\
1827 \\
4107 \\
\end{array}$ & $\begin{array}{r}-4017 \\
-1151 \\
-3964 \\
-1067 \\
-780 \\
-1169 \\
\end{array}$ & $\begin{array}{r}44640 \\
7757 \\
79917 \\
9887 \\
5427 \\
6198 \\
\end{array}$ & $\begin{array}{r}-1194 \\
-125 \\
-636 \\
-126 \\
-241 \\
-313 \\
\end{array}$ & $\begin{array}{r}37949 \\
7682 \\
32048 \\
8832 \\
5011 \\
7564 \\
\end{array}$ \\
\hline Total & 21426 & $\overline{2862}$ & 67388 & 17632 & -12148 & 148826 & -2635 & 99086 \\
\hline
\end{tabular}


related hinterland industries and (b) employee requirements of the industries producing substitutes for other imported commodities, and because of the mix of its import decreases, the Gulf area would experience a net increase in employment.

Exports. Table 4 shows the geographic distribution of the effects from the decline in exports resulting from the $\$ 0.25$ per ton charge. While the distribution is somewhat different from that exhibited by the decrease in imports, the effects are straightforward. Of the areas delineated for this study, the Gulf of Mexico exports, by far, the greatest tonnage. It would, therefore, experience the largest economic effects among the areas as a consequence of the
$\$ 0.25$ charge on exports. Both its port/shipping industry and the hinterland industries supplying its exports would show the greatest decline in sales, employment and income.

Paradoxically, the Gulf would not experience the greatest decline in export tonnage shipped. The amounts exported through the Great Lakes port system would decline more than those of any other area. However, because of the nature of the products shipped and the characteristics of the Great Lakes port/shipping industry compared to those in the other areas, the absolute loss of jobs and income on the Lakes would not be as great as in the Gulf, the North Atlantic, and the Pacific Northwest.

Table 4

Ecomomic Effects of a User Charge on U.S. Deep Water Commerce CHANGES IN EXPORTS, 1979, BY PORT AREA (1979 Dollars)

User Charge $=\$ .25$ per ton of Imports, Exports, Domestic Unloadings

\begin{tabular}{|c|c|c|c|c|c|c|c|c|}
\hline INDUSTRY/AREA & $\begin{array}{l}\text { Direct } \\
\text { Sales } \\
\$ 1000\end{array}$ & $\begin{array}{c}\text { Employ- } \\
\text { ment } \\
\text { Jobs }\end{array}$ & $\begin{array}{c}\text { Income } \\
\$ 1000 \\
\end{array}$ & $\begin{array}{l}\text { Taxes } \\
\$ 1000 \\
\end{array}$ & $\begin{array}{c}\text { Duties } \\
\$ 1000\end{array}$ & $\begin{array}{c}\text { User } \\
\text { Charge } \\
\$ 1000\end{array}$ & $\begin{array}{c}\text { Cargo } \\
1000 S T\end{array}$ & $\begin{array}{c}\text { Commodity } \\
\text { Balance } \\
\$ 1000\end{array}$ \\
\hline \multicolumn{9}{|l|}{ Port/Shipping Industry } \\
\hline North Atlantic & -2341 & -182 & -4182 & -1092 & - & 19180 & -337 & -27038 \\
\hline South Atlantic & -237 & -18 & -423 & -111 & - & 2715 & -26 & -5174 \\
\hline Gulf of Mexico & -3456 & -268 & -6173 & -1612 & - & 37623 & -618 & -73071 \\
\hline California & -462 & -36 & -824 & -215 & - & 5707 & -77 & -9515 \\
\hline Pacific Northwest & -1599 & -124 & -2857 & -746 & - & 11714 & -277 & -21615 \\
\hline Great Lakes & -1501 & -117 & -2680 & -700 & - & 11988 & -724 & -18486 \\
\hline Total & -9596 & -746 & -17140 & -4476 & - & 88928 & -2060 & -154905 \\
\hline \multicolumn{9}{|l|}{ Hinterland Industry } \\
\hline North Atlantic & -27038 & -2027 & -50810 & -13128 & - & - & - & - \\
\hline South Atlantic & -5174 & -394 & -9709 & -2501 & - & - & - & - \\
\hline Gulf of Mexico & -73071 & -4441 & -117729 & -30362 & - & - & - & - \\
\hline California & -9515 & -630 & -15873 & -4231 & - & - & - & - \\
\hline Pacific Northwest & -21615 & -1506 & -36887 & -9333 & - & - & - & - \\
\hline Great Lakes & -18488 & -1288 & -32494 & -8506 & - & - & - & - \\
\hline Total & -154905 & -10286 & -263506 & -68059 & - & - & - & - \\
\hline \multicolumn{9}{|l|}{ Total } \\
\hline North Atlantic & -29379 & -2209 & -54992 & -14220 & - & 19180 & -337 & -27038 \\
\hline South Atlantic & -5411 & -412 & -10132 & -2612 & - & 2715 & -26 & -5174 \\
\hline Gulf of Mexico & -76527 & -4709 & -123902 & -31974 & - & 37623 & -618 & -73071 \\
\hline California & -9977 & -666 & -16697 & -4446 & - & 5707 & -77 & -9515 \\
\hline Pacific Northwest & -23214 & -1630 & -39744 & -10079 & - & 11714 & -277 & -21615 \\
\hline Great Lakes & -19989 & -1405 & -35174 & -9206 & - & 11988 & -724 & -18486 \\
\hline Total & -164501 & -11032 & -280646 & -72535 & - & 88928 & -2060 & -154905 \\
\hline
\end{tabular}




\section{Industrial Sector Impacts}

Tables 5(a) and 5(b) show the impacts that the $\$ 0.25$ per ton charge would ultimately have on the various sectors of the economy. The 30 sectors shown in the table are aggregations of the original 476 sectors of the input-output model.

Within the effects on the port/shipping industry (Table 5(a)), the largest direct impact of the charge falls upon the Deep Sea and Great Lakes water transportation sectors, composed primarily of the carriers. The insurance sector also experiences a decline in direct sales as a result of the decrease in the separate commodity insurance that would be taken out by shippers. However, as the effects of these cutbacks in sales are transmitted throughout the economy,

Table 5(a)

Economic Effects of a User Charge on U.S. Deep Water Commerce ALL COMMERCE, TOTAL U.S., 1979 BY INDUSTRY/PRODUCT SECTOR (1979 Dollars)

User Charge $=\$ .25$ per ton of Imports, Exports, Domestic Unloadings

Port/Shipping Effects

\begin{tabular}{|c|c|c|c|c|c|c|c|c|}
\hline $\begin{array}{l}\text { INDUSTRY/ } \\
\text { PRODUCT }\end{array}$ & $\begin{array}{l}\text { Direct } \\
\$ 1000\end{array}$ & $\begin{array}{l}\text { +Indirect } \\
\$ 1000\end{array}$ & $\begin{array}{c}\text { +Induced } \\
\$ 1000\end{array}$ & $\begin{array}{c}\text { Employment } \\
\text { Persons }\end{array}$ & $\begin{array}{c}\text { Income } \\
\$ 1000\end{array}$ & $\begin{array}{l}\text { Taxes } \\
\$ 1000\end{array}$ & $\begin{array}{l}\text { Duties } \\
\$ 1000\end{array}$ & $\begin{array}{l}\text { Tonnage } \\
\text { K Tons }\end{array}$ \\
\hline Food and Feed Grains & 0.0 & -22.92 & -803.16 & -13.20 & -394.04 & -66.57 & 0.63 & -473.04 \\
\hline Oil Bearing Crops & 0.0 & -9.22 & -202.87 & -2.15 & -118.00 & -19.76 & 0.0 & -48.37 \\
\hline \multicolumn{9}{|l|}{ Agriculture nec. } \\
\hline Forestry, Fisheries & 0.0 & -144.72 & -3932.57 & -78.12 & -1196.02 & -242.99 & -17.11 & -7.97 \\
\hline Metal Ores & 0.0 & -127.13 & -298.67 & -3.37 & -126.80 & -39.04 & -2497.04 & -1358.03 \\
\hline Coal & 0.0 & -169.02 & -566.21 & -6.71 & -292.11 & -58.81 & -152.34 & -566.26 \\
\hline \multicolumn{9}{|l|}{ Crude Petroleum \& } \\
\hline Natural Gas & 0.0 & -4305.09 & -7102.59 & -29.43 & -4078.20 & -863.61 & -910.83 & -236.22 \\
\hline Minerals nec. & 0.0 & -41.96 & -153.29 & -1.92 & -84.25 & -18.22 & -2751.93 & -5376.71 \\
\hline Construction & 0.0 & -1225.28 & -2878.49 & -41.65 & -1631.85 & -313.22 & 0.0 & 0.0 \\
\hline \multicolumn{9}{|l|}{ Food and Tobacco } \\
\hline Products & 0.0 & -209.33 & -8237.85 & -60.54 & -1805.09 & -665.44 & -377.87 & -77.70 \\
\hline Textiles and Apparel & 0.0 & -267.60 & -368 & $-c$ & -11 & -22 & -47.21 & -0.30 \\
\hline \multicolumn{9}{|l|}{ Wood, Lumber and } \\
\hline Furniture & 0.0 & -221.31 & -1252.87 & -25.62 & -421.70 & -83.02 & -355.80 & -142.58 \\
\hline Paper and Publishing & 0.0 & -687.13 & -3865.32 & -62.47 & -1527.70 & -298.13 & -93.63 & -17.46 \\
\hline \multicolumn{9}{|l|}{ Chemicals, Plastics, } \\
\hline Drugs, Paint, Rub'r & 0.0 & -949.68 & -4929.59 & -50.11 & -1691.08 & -360.79 & -306.52 & -75.75 \\
\hline Petroleum Refining & 0.0 & -6488.91 & -10071.84 & -12 & -815.14 & -518.87 & -2902.25 & -986.56 \\
\hline nd Footwear & 0.0 & -5.97 & -456.81 & -12 & -163.06 & -34.68 & 27.60 & -0.10 \\
\hline Glass, Stone and Clay & 0.0 & -135.14 & -644.70 & -12.18 & -302.91 & -60.82 & -527.00 & -110.38 \\
\hline Metals Manufacturing & 0.0 & -2574.14 & -5987.76 & -66.32 & -2007.47 & -416.14 & -941.87 & -30.86 \\
\hline \multicolumn{9}{|l|}{ Machinery and } \\
\hline Appliances nec. & 0.0 & -1531.44 & -3943.75 & -66.69 & -1698.98 & -333.42 & -60.27 & -2.81 \\
\hline \multicolumn{9}{|l|}{ Shipbuilding \& } \\
\hline \multirow{2}{*}{\multicolumn{9}{|c|}{ Transportation }} \\
\hline & & & & & & & & \\
\hline Equipment & 0.0 & -273.21 & -3649.04 & -31.32 & -1067.73 & -221.07 & -135.31 & -0.89 \\
\hline ents \& Misc. & & & & & & & & \\
\hline Mfg. & 0.0 & -402.88 & -1482.09 & -30.53 & -611.66 & -120.80 & -39.70 & -0.20 \\
\hline \multicolumn{9}{|l|}{ Transportation, Com- } \\
\hline Insurance & -116.65 & -1793.78 & -4386.42 & -10 & -1 & -5 & 0.0 & 0.0 \\
\hline \multicolumn{9}{|l|}{ Trade, Finance \& } \\
\hline Services nec. & 0.0 & -8253.09 & -48693.09 & -1468.69 & -28466.07 & -8844.44 & 0.0 & 0.0 \\
\hline $\begin{array}{l}\text { Ordnance, Gov't Enter- } \\
\text { prises, Dummy Ind. }\end{array}$ & 0.0 & -4264.76 & -6302.59 & -154.91 & 1413.90 & -284.19 & -0.03 & 0.0 \\
\hline \multicolumn{9}{|l|}{ Deep Sea Foreign } \\
\hline Trans. & -16889.64 & -16889.64 & -16906.94 & -102.66 & -5281.51 & -1151.11 & 0.0 & 0.0 \\
\hline \multicolumn{9}{|l|}{ Deep Sea Domestic } \\
\hline cakes Trans & -11973.46 & -11946.78 & -11966.04 & -41.82 & -44 & -971.46 & 0.0 & 0.0 \\
\hline Great Lakes Trans. & -10148.48 & -10134.48 & -10137.42 & -50.84 & -3923.38 & -855.10 & 0.0 & 0.0 \\
\hline Inland \& Local Trans. & 0.0 & -655.09 & -666.82 & -54.00 & -205.81 & -44.86 & 0.0 & 0.0 \\
\hline Water Trans. Services & 0.0 & -15267.32 & -15329.54 & -362.87 & -3727.94 & -812.55 & 0.0 & 0.0 \\
\hline \multicolumn{9}{|l|}{ Total (inc. Directly } \\
\hline Allocated) & -39128.22 & -94531.13 & -191819.56 & -3267.37 & -77193.44 & -20175.36 & -12146.81 & -9511.9 \\
\hline
\end{tabular}


local water transportation and water transportation services-i.e., deepwater port services such as tugs, dock operations, stevedoring and chandlering-show significant indirect sales losses, as do the trade, finance and other services sectors. Because of the significant fuel cost component of shipping operations, crude petroleum and petroleum refining sectors are also among those which experience the larger indirect impacts.

The total effects on sales are spread even more widely when the induced feedback, created by cuts in household consumption in response to lower incomes, works its way

Table 5(b)

Economic Effects of a User Charge on U.S. Deep Water Commerce ALL COMMERCE, TOTAL U.S., 1979 BY INDUSTRY/PRODUCT SECTOR (1979 Dollars)

User Charge $=\$ .25$ per ton of Imports, Exports, Domestic Unloadings

Hinterland Effects

\begin{tabular}{|c|c|c|c|c|c|c|c|c|}
\hline $\begin{array}{l}\text { INDUSTRYI } \\
\text { PRODUCT } \\
\end{array}$ & $\begin{array}{l}\text { Direct } \\
\$ 1000 \\
\end{array}$ & $\begin{array}{c}\text { +Indirect } \\
\$ 1000 \\
\end{array}$ & $\begin{array}{c}\text { +Induced } \\
\$ 1000 \\
\end{array}$ & $\begin{array}{c}\text { Employment } \\
\text { Persons }\end{array}$ & $\begin{array}{c}\text { Income } \\
\$ 1000 \\
\end{array}$ & $\begin{array}{l}\text { Taxes } \\
\$ 1000 \\
\end{array}$ & $\begin{array}{c}\text { Charges } \\
\$ 1000 \\
\end{array}$ & $\begin{array}{c}\text { Exp. Bal. } \\
\$ 1000\end{array}$ \\
\hline Food and Feed Grains & -46813.2 & -51733.3 & -53059.3 & -871.8 & -26031.7 & -4397.6 & 27394.3 & -56333.5 \\
\hline Oil Bearing Crops & -11539.5 & -16345.3 & -16673.6 & -177.0 & -9698.1 & -1624.0 & 5725.9 & 976.0 \\
\hline \multicolumn{9}{|l|}{ Agriculture nec. } \\
\hline Forestry, Fisheries & -1913.6 & -11751.8 & -18187.9 & -390.3 & -6514.6 & -1261.7 & 2077.1 & -2944.6 \\
\hline Metal Ores & 15807.4 & 17148.1 & 16861.6 & 166.5 & 6965.8 & 2171.0 & 35133.3 & 13168.6 \\
\hline Coal & -9066.3 & -10653.2 & -11319.7 & -134.4 & -5829.4 & -1173.6 & 23593.4 & -19445.9 \\
\hline \multicolumn{9}{|l|}{ Crude Petroleum \& } \\
\hline Natural Gas & 1670.3 & -27617.1 & -30980.2 & -129.2 & -17372.6 & -3676.6 & 19916.7 & 19912.6 \\
\hline Minerals nec. & 4025.0 & 2433.8 & 2248.7 & 44.3 & 1812.0 & 357.3 & 22561.7 & -2614.9 \\
\hline Construction & 0.0 & -4797.2 & -7525.6 & -108.9 & -4266.3 & -818.9 & 61.7 & 0.0 \\
\hline \multicolumn{9}{|l|}{ Food and Tobacco } \\
\hline Products & -9986.9 & -12785.4 & -26427.8 & -155.1 & -4720.5 & -1645.8 & 10560.0 & -11720.2 \\
\hline Textiles and Apparel & 564.4 & 251.4 & -5557.0 & -137.7 & -1673.4 & -334.3 & 509.0 & 399.4 \\
\hline \multicolumn{9}{|l|}{ Wood, Lumber and } \\
\hline Furniture & -6874.7 & -9353.9 & -11101.1 & -159.0 & -3219.7 & -606.5 & 8819.1 & -8791.8 \\
\hline Paper and Publishing & -3783.0 & -6506.8 & -11883.5 & -1 & -4454.1 & -870.3 & 2390.3 & -4576.9 \\
\hline \multicolumn{9}{|l|}{ Chemicals, Plastics, } \\
\hline Drugs, Paint, Rub'r & -10391.7 & -26940.3 & -33597.5 & -269.6 & -11449.8 & -2374.8 & 11218.4 & -8894.1 \\
\hline Petroleum Refining & -32957.5 & -42658.3 & -46721.7 & -55.2 & -3763.2 & -2399.8 & 147568.8 & 23817.1 \\
\hline and Footwear & 415.6 & 520.9 & -245.6 & -5.9 & -84.4 & -18.1 & 134.6 & 348.6 \\
\hline Glass, Stone and Clay & 3317.4 & 3092.5 & 2233.1 & 19.6 & 1034.2 & 211.8 & 3747.1 & 2654.4 \\
\hline Metals Manufacturing & 10837.5 & 10518.8 & 4792.2 & 22.1 & 1194.9 & 273.4 & 7308.0 & 9299.5 \\
\hline \multicolumn{9}{|l|}{ Machinery and } \\
\hline \multicolumn{9}{|l|}{ Shipbuilding \& } \\
\hline Boatbuilding & 10.4 & -225.0 & -378.1 & -8.5 & -135.9 & -28.6 & 20.6 & 7.2 \\
\hline \multicolumn{9}{|l|}{ Transportation } \\
\hline Equipment & 1716.8 & 1429.1 & -4307.4 & -38.2 & -1320.8 & -274.0 & 1459.0 & 1453.6 \\
\hline Mfg. & 454.0 & 187.4 & -1642.7 & -31 & -716.9 & -1 & 329.6 & 349.8 \\
\hline \multicolumn{9}{|l|}{$\begin{array}{l}\text { Transportation, Com- } \\
\text { munications, }\end{array}$} \\
\hline Utilities & -19350.4 & -31136.9 & -43986.0 & -763.9 & -23503.0 & -5748.5 & 71.8 & 0.0 \\
\hline Insurance & 0.0 & -1761.5 & -6159.8 & -143.7 & -2495.9 & -733.6 & 14.2 & 0.0 \\
\hline \multicolumn{9}{|l|}{ Trade, Finance \& } \\
\hline Services nec. & -10248.9 & -37168.3 & -105634.6 & -2976.6 & -60788.5 & -20657.2 & 349.6 & 0.0 \\
\hline $\begin{array}{l}\text { Ordnance, Gov't Enter- } \\
\text { prises, Dummy Ind. }\end{array}$ & -1.3 & -1 & 8: & - & U10. & 710 & 3399.1 & -1 \\
\hline \multicolumn{9}{|l|}{ Deep Sea Foreign } \\
\hline Trans. & 0.0 & 0.0 & -29.5 & -0.2 & -9.2 & -2.0 & 0.9 & 0.0 \\
\hline \multicolumn{9}{|l|}{ Deep Sea Domestic } \\
\hline Trans. & -860.7 & -858.4 & -891.1 & -3.1 & -331.9 & -72.3 & 0.7 & 0.0 \\
\hline Great Lakes Trans. & -250.6 & -250.3 & -255.3 & -1.3 & -98.8 & -21.5 & 0.1 & 0.0 \\
\hline Inland \& Local Trans. & -1191.8 & -1222.7 & -1242.7 & -15.1 & -453.6 & -98.9 & 0.4 & 0.0 \\
\hline \multirow{2}{*}{$\begin{array}{l}\text { Water Trans. Services } \\
\text { Total (inc. Directly }\end{array}$} & 0.0 & -1122.3 & -1228.2 & -29.1 & -298.7 & -65.1 & 1.1 & 0.0 \\
\hline & & & & & & & & \\
\hline Allocated) & -126065.9 & -262860.5 & -423942.8 & -6846.1 & -182851.9 & -46958.2 & 336846.9 & -55816.3 \\
\hline
\end{tabular}


through the system. The initial impacts of the decline in port traffic are experienced most directly by the deep water transportation sectors. However, when the full set of effects has been estimated, the largest absolute losses in employment and income are shown in the wholesale and retail trade, finance and services sectors, reflecting the extent of these sectors' contributions to the production and distribution of goods and services in the economy.

Among the hinterland industries (Table 5(b)), the net effects of the impacts generated by the $\$ 0.25$ per ton charge are distributed quite unevenly and in some instances in opposite directions. The first column in the table shows the net direct effects on the various sectors from the changes in imports and exports resulting from the charge.

Again, in the 30-sector aggregation, shown in Table 5(b), of the original 476-sector breakdown, the sector composed of trade, finances and other services would experience the largest decrease in employment, income and tax payments as the full impacts work through the system (column 3). The agricultural sectors, petroleum and chemical sectors, and coal mining also experience declines. These declines are small, however, relative to the magnitudes of the national output, employment and income totals for the individual industries. Only in the cases of the water transportation sectors do the percentage losses approach one percent or more of the original national levels of sector employment and income.

\section{Conclusions}

This analysis demonstrates quite clearly that levying a charge on waterborne imports and exports and on coastal and Great Lakes deepwater unloadings does not result simply in a straightforward increase in government revenues. The analysis shows that the imposition of a user charge can be expected to cause (1) declines in the sales transactions of the carrier, port, and supporting industries supplying the deepwater transportation services, and (2) a variety of adjustments in the sales of those hinterland industries which produce goods that are exported and those which consume or displace goods that are imported. On balance, it was shown that the port/shipping industry and the hinterland industries would experience declines in sales, employment, and income. It was also shown that, as a result, customs duties collections would decrease, as would federal, state and local income and indirect business tax collections. Additionally, there would be an initial decline in the commodity balance of trade (the estimated decrease in the value of U.S. exports exceeds the estimated decrease in the value of imports). The ultimate advisability of such a levy, its magnitude, and its timing depend on the importance attached to the additional revenues collected by the user charge relative to the importance of the changes effected in the measures of economic performance.

\section{FOOTNOTES}

\begin{abstract}
'The tonnage is a levy per net registered ton of a foreign trade vessel upon each entry it makes into any U.S. port, up to five in any one year. Light money charges are similarly levied upon the net registered tonnage of foreign trade vessels but is so called because it is supposedly compensation for maintenance of navigation aids. In fiscal year 1982, total tonnage tax and light money collections by Customs were approximately $\$ 14$ million. (Communication from the Bureau of Customs).
\end{abstract}

\section{REFERENCES}

Anderson, D. L., R. W. Schuessler and P. A. Cardellichio. 1977a. Deep-Draft Navigation User Charges: Recovery Options and Impacts. Cambridge: Transportation Systems Center, U.S. Department of Transportation. $1977 \mathrm{~b}$. Regional Market, Industry,

and Transportation Impacts of Waterway User Charges. Cambridge: Transportation Systems Center, U.S. Department of Transportation.

Baldwin, R. E. 1976. U.S. Tariff Policy: Formation and Effects. Washington, D.C.: Office of Foreign Economic Research, Bureau of International Labor Affairs, U.S. Department of Labor.

Bennathan, E. and A. A. Walters. 1979. Port Pricing and Investment Policy for Developing Countries. New York: Oxford University Press.

Buckler, M. and C. Almon. 1972. "Imports and Exports in an Input-Output Model," American Statistical Association Proceedings of the Business and Economic Statistics Section. 175-184.

Bureau of Economic Analysis, U.S. Department of Commerce. 1979a. The Detailed Input-Output Structure of the U.S. Economy: 1972. Vols. I \& II. Washington, D.C.: U.S. Government Printing Office.

Bureau of Economic Analysis, U.S. Department of Commerce. 1979b, 501 Sector Model of the U.S. Economy Emphasizing the Waterborne Commerce Sectors. (Prepared by P. Ritz et al. for the Maritime Administration). Washington, D.C.

Bushnell, Pearsall and Trozzo. 1984. Economic Effects of Levying a User Charge on Foreign and Domestic Commerce to Finance Harbor Maintenance. Report prepared for the U.S. Department of Commerce, Economic Development Administration. Appendix C.

Charles River Associates. 1970. A Study of the Inland Waterway User Charge Program. Cambridge, Mass.

Davis, H. C. 1983. "Regional Port Impact Studies: A Critique and Suggested Methodology," Transportation Journal 23(2), 61-71. 
Evans, D. 1955. "Input-Output Coefficients," in T. Barna (ed.) Structural Interdependence of the Economy. New York: John Wiley \& Sons, 53-102.

Heggie, I. 1974. "Charging for Port Facilities," Journal of Transport Economics and Policy 8(1), 3-25.

Imakita, J. 1978. "Port Pricing Policy," in A TechnoEconomic Analysis of the Port Transport System. Westmead, England: Saxon House, 160-183.

Lofting, E. M. and H. C. Davis. 1982. National, State, and Local Area Multipliers with Emphasis on the Minerals, Fueh and Energy Sectors. University of California: Lawrence Berkeley Laboratory.

Salzano, C. J. 1981. "No User-Charge Consensus Reached by AAPA at Los Angeles Convention," Traffic World 188(6), 30-35.

Tomassoni, M. E. 1981. "Collecting the User Fee," American Shipper 23, 42-46.
U.S. Bureau of the Census. 1979b. Magnetic data tape EM522.

U.S. Buerau of the Census. 1979a. Magnetic data tape IA245.

U.S. Corps of Engineers, U.S. Department of the Army. 1979. Waterborne Commerce of the United States. Parts 1-5.

Walters, A. A. 1975. "Marginal Cost Pricing in Ports," The Logistics and Transportation Review 11(4), 297-308.

Walton, M. C. 1979. Inland Waterway User Charges, Port Development, and Research Methodologies. Washington, D.C.: Transportation Research Board.

Waters, W. G. 1976. "Impact Studies and the Evaluation of Public Projects," Annals of Regional Science, 10(1), 98-103. 